Avalaible online: https://ejournal.iai-tribakti.ac.id/index.php/pgmi

Article doi: https://doi.org/10.33367/jiee.v1i2.953

Submission: 2019-10-22 Review: 2019-10-23 Accepted: 2019-10-24

\title{
METONIMI DAN METAFORA JAQUES LACAN DALAM SUBJEK LAGU CIDRO
}

\author{
Silmi Rozida \\ Institut Agama Islam Tribakti Kediri \\ mishilisme@gmail.com
}

\begin{abstract}
Language is no longer divided due to meaning, but language is part of the consequences of emptiness. Desire is a form of lack of a subject on the object that he desires. A work is a manifestation of the desire of its creator. Didi Kempot (hereinafter Dk) and his poem entitled "cidro" is part of the subject entity with its desires. Lacan refers to a subject that is free, in this case DK as a manifest subject frees his desires through metonymy and metaphor.
\end{abstract}

Key Word: Subject, Desire, Cidro

\begin{abstract}
Abstrak
Bahasa tidak lagi terpecah akibat makna, akan tetapi bahasa merupakan bagian dari akibat kekosongan. Hasrat merupakan bentuk rasa kekurangan seorang subjek pada benda yang dihasratinya. Sebuah karya merupakan manifes dari hasrat penciptanya. Didi Kempot (selanjutnya Dk) dan syairnya yang berjudul "cidro" merupakan bagian dari entitas subjek dengan hasratnya. Lacan mengidelkan sebuah subjek yang terbebas, dalam hal ini DK sebagai manifest subjek membebaskan hasratnya melalui metonimi dan metafora.
\end{abstract}

Kata Kunci: Subjek, Hasrat, Cidro

\section{Pendahuluan}

Campursari merupakan genre yang (crossover) campuran semua jenis musik. Setelah kemunculan Didi Kempot dalam berbagai acara dan julukan sebagai "the god father of broken heart" memberikan pandangan baru terhadap genre ini terhadap anak kalangan muda. Setelah lagu lawasnya balapan "Stasiun Balapan”, pada tahun 2019 Didi Kempot mengeluarkan single barunya yang berjudul "Cidro". Lagu ini dibawakan oleh Didi dengan menarik banyak khalayak muda untuk menikmatinya. Kemundulan "cidro" ini juga ditandai dengan keadaan masyarakat indonesia 66 yang mengeluarkan mosi tidak percaya terhadap negara. sehingga, lagu ini juga selain merayakan patah hati juga mengimplementasikan kekecewaan terhadap kondisi politik indonesia. hal ini ditunjukan pada beberapa aksi meminjam "cidro" sebagai curahan hati pengunjuk rasa.

Pada tulisan ini akan melihat lebih dalam lagi dari lirik lagu "Cidro" karya Didi kempot dengan perspektif Psikoanalisa Jacques Lacan. Metonimia dan metafora merupakan alat Lacan dalam menjelaskan ketaksadaran di dalam sebuah karya. Sedangkan karya merupakan tempat bagi pengarang untuk

el Bidayah: Journal of Islamic Elementary Education Volume 1, Nomor 2, September 2019 
mencurahkan hasrat yang mereka idealkan. Tokoh-tokoh di dalamnya misalkan saja "Aku" yang dihadirkan di dalam dunia imajiner pengarang memiliki identitas yang sebelumnya sudah dianggap oleh pengarang sebagai manifestasi hasratnya.

Seseorang berbicara atau menulis, ia selalu mewujudkan diri dengan bahasa, dengan penanda-penanda. Penandapenanda adalah satu-satunya cara subjek itu dapat mewujudkan dirinya. ${ }^{1}$ Seorang pengarang menyembunyikan hasratnya melalui bahasa dengan implisit. Menurut Lacanian bahasa adalah media dalam memanifeskan hasrat pengarang merupakan alat penting dalam psikoanalisa. Hal ini merupakan pembedahan karya secara intrinsik melalui bahasa, dan melalui bahasa itulah wacana sosial yang terjadi di dalam teks oleh hasrat pengarang akan dapat dibaca.

Terdapat beberapa tahap dalam pembentukan diri, Lacan mengatakan bahwa tahapan tersebut dipengaruhi oleh tiga fase. Pertama fase pra-odipal, fase cermin, dan fase odipal. Fase pra- odipal disebut juga dengan fase tatanan real (the real), kemudian fase cermin sebagai tatanan imajiner (the imaginary), dan yang terakhir adalah fase odipal atau tatanan simbolik (the symbolic).

Pada tahap pra odipal, sejalan dengan Freud bahwa Lacan juga sependapat bahwa fase saat bayi belum mengenali dirinya sendiri dan batasan egonya. Bayi masih merasa menjadi satu dengan ibunya. Dalam fase berikutnya, fase di mana bayi menyadari keterpisahan nya dengan ibunya. Fase ini dinamakan fase cermin, dan fase ini memiliki

1 Philip Hill, Lacan Untuk Pemula (Yogyakarta: Kanisius, 2002), h. 29-30. beberapa tahapan, pertama bayi merasa terpisah dari ibunya, kemudian bayi merasa ingin kembali menyatu dengan ibunya. Dalam fase ini bayi masih belum mengetahui konsep diri-nya. Hal ini mnegakibatkan bayi membawa pada keadaan di mana kebutuhan menjadi permintaan. Kebutuhan yang tidak terpenuhi membuat bayi meminta. Sedangkan permintaan bayi tersebut tidak dapat diartikulasikan dengan benar, yang mana mengakibatkan ibu tidak dapat memberikan pemenuhan atas permintaan bayi, dan kemudian bayi hanya dapat memberitahukan ibu dengan cara menangis. Hal ini karena bayi belum memiliki bahasa.

Terpenting berikutnya adalah di mana terjadi proses identifikasi pada bayi. Imajiner adalah istilah yang dipakai Lacan untuk menyebut proses pembentukan subjek yang didominasi oleh identifikasi dan dualitas, sebelum pengenalan pada bahasa. ${ }^{2}$ Pembentukan subjek tersebut dipaparkan dalam fase cermin. Ketika bayi menghadap ke cermin akan terpantul bayangan diri. Seperti dalam bukunya, Identifikasi menurut Lacan adalah suatu transformasi yang terjadi pada benak subjek saat ia membayangkan suatu citra, seperti yang ditulisnya dalam artikel panjangnya, Ecrits: "the transformation that takes place in the subject when he assumes an image". 3 Saat bayi dapat melihat pantulan dirinya di dalam kaca, akan terjadi kesalah pahaman diri atau disebut juga sebagai (misrecognition). Setelah itu bayi kana membuat konstruksi

2 Agustinus Hartono, Skizoanalisi Deleuze Guattari: Sebuah Pengantar Genealogi Hasrat (Yogyakarta: Jala Sutra, 2007), h. 23.

3 Jacques Lacan, Ecrits: A Selection. Terjemahan Alan Sheridan (London: Tavistock, 1977), h. 2. 
imajiner dengan membuat "ego ideal". Setelah bayi dewasapun ia akan membuat identifikasi imajiner dengan benda-benda yang ditemuinya.

Fase ke tiga, merupakan fase anak harus mengalami kastrasi, di mana ibu dilihat sebagai liyan, ibu tak lagi dipandang sebagai satu kesatuan pada diri anak. Fase ini dinamakan dengan fase odipal. Di mana terjadi keterpisahan antara anak dan ibu. Kemudian muncul 'ayahsimbolik, hal ini juga menyebabkan hubungan antara ibu dan anak semakin berjarak. Kehadiran 'ayah simbolik' menyebabkan anak kehilangan obyek hasratnya, yakni ibu (liyan). Konsep liyan ('l' kecil) merujuk pada objek hasrat yang disebut Lacan sebagai objek $a$. Sedangkan Liyan ('L' kapital) merupakan pusat otoritas kultural Simbolik. Oleh Freud dinamakan sebagai Phallus. ${ }^{4}$

Objek $a$ oleh Lacan disebut sebagai objek penyebab hasrat. Hasray menciptakan kesalahan persepsi tentang kehilangan dan kemudian hal tersebutlah yang menyebabkan terjadinya kecemasan (anxiety). Hasrat dalam Lacan selalu berkaitan dengan yang lain. hal ini mengakuisisi bahwa objek dapat memberikan joisance atau kenikmatan. Dalam Lacan kenikmatan bersifat paradok, yakni membawa kesenangan dan peneritaan. Untuk memahami bagaimana subjek terus-menerus menginginkan objek $a$ yang senyatanya tidak akan pernah didapatkan dengan memahami fase cermin ke dua yakni komplek odipus dan bahasa.

Lacan meminjam triangulasi Freud dalam menjelaskan konsep cermin ke dua

4 Jacque Lacan dan S. Tomaselli, The Ego in Freud's Theory and in the Technique of Psycoanalysis (London: W.W. Norton \& Company, 1988), h. 242-247.

68 ini sebagai pencitraan diri anak, anak mempelajari konsep citra. Pada tahap kompleks odipus dipresentasikan oleh orang tua. Dalam artian identitas subjek terbentuk dari ayah-ibu. Freud menyebut sebagai ayah biologis, akan tetapi oleh Lacan diubah sebagai ayah simbolik.konsep atas-nama-ayah merupakan rangkaian yang membentuk identitas anak.

Bahasa merupakan representasi dominan sebagai identifikasi subjek. Menurut Lacan, subjek ditentukan oleh bahasa, malahan subjek tidak mungkin ada tanpa bahasa. Dengan kata lain, tidak ada subjek yang bebas dari bahasa. Semua subjek tenggelam dalam bahasa dan tidak pernah lepas dari bahasa sehari-hari. Semua manusia mempresentasikan diri melalui bahasa dan bahasa adalah jalan menuju domain sosial. ${ }^{5}$

Metafora dan metonimi dalam lacan bukanlah bahasa yang dikatakan seperti Saussure, melainkan sebuah negosiasi penanda-penanda (tidak hanya satu penanda). Dijelaskan kembali bahwa bahasa yang menjadi bagian dari ketidak sadaran subjek. Bahasa tersebut merupakan bentuk lain dari hasrat subjek. Pada lacan metonimia sebagai satu bentuk jalannya keterhubungan antara penanda ${ }^{6}$ satu kepada penanda yang lain dalam sebuah rantai bahasa. dan dengan akhirnya melalui bahasa memberikan jalur antara identifikasi dan hasrat. menyebutnya

${ }^{5}$ Hartono, h. 26-27.

6 . Indicating that it is the connection between signifier and signifier that permits the closing by which the signifier installs the lack of being in the object relation, using the value of reference-back possessed by signification in order to invest it with the desire aimed at the very task it supports.

el Bidayah: Journal of Islamic Elementary Education Volume 1, Nomor 2, September 2019 
sebagai persekutuan dan pertentangan pada penanda-penanda. ${ }^{7}$

Menurut Lacan tidak ada penanda yang jauh dari Metaforitas ( metafora adalah penanda yang menandakan penanda lain). dalam Sarup mengatakan bahwa tidak ada makna yang tepat dalam menjelaskan penanda metafor dan setiap penanda dapat menerima pemaknaan, hal ini dijelaskan bahwa makna dalam penanda tidak ada yang memuaskan. ${ }^{8}$ Metafora mempresentasikan salah satu cara untuk menstruktur pelbagai macam wacana $^{9}$

Berdasarkan pemaparan di atas maka masalah yang di rumuskan oleh peneliti adalah bagaimana hasrat yang berkekurangan (lack) Didi sebagai pelantun dan pengarang "Cidro" . tujuan dari penelitian ini adalah mengidentifikasi hasrat melalui metafora dan metonimia yang terdapat dalam subjek hasrat pengarang serta mendiskripsikan bagaimana hasrat subjek dapat terbentuk.

\section{Metode Penelitian}

Psikoanalisa berasal dari pandangan Freud yang kemudian dikembangkan kembali oleh Lacan. Objek penelitian ini merupakan sebuah teks lirik "Cidro" karya Didi Kempot (selanjutnya DK). Metode yangpertama kali dilakukaan adalah membaca dari teks

7 Mark Bracher dan Jaques Lacan, Diskursus dan Perubahan Sosial: Pengantar Kitik-Budaya Psikoanalisi, trans. oleh Gunawan Admiranto (Yogyakarta: Jala Sutra, 2009).

8 Madan Sarup, Panduan Pengantar

Untuk Mehami Postrukturalisme dan Postmodernisme, trans. oleh Medhy AgintaHidayat (Yogyakarta: Jala Sutra, 2011), h. 10 .

9 Fina Hiasa, "Kerinduan Pada yang Real Dalam Novel Akar Karya Dee," Jurnal POETIKA 4, no. 2 (30 Desember 2016): 66, https://doi.org/10.22146/poetika.15650.

el Bidayah: Journal of Islamic Elementary Education

Volume 1, Nomor 2, September 2019 tersebut dan mencari subjek. Dalam pembentukan identitas subjek terdapat sebuah hasrat subjek. Alam bawah sadar lah yang mengirim hasrat, dan hasrat berasal dari ego. Menurut Prof. Faruk teori psikoanalisis Lacan menganggap alam bawah sadar manusia selalu dalam keadaan "kurang", merasa ada yang hilang sehingga tumbuh hasrat dan usaha yang terus-menerus untuk menutupi kekurangan itu, menemukan kembali apa yang hilang, membuat manusia kembali lengkap, sempurna, utuh, menemukan identitasnya, menjadi dirinya kembali. ${ }^{10}$

\section{Pembahasan}

Didi merupakan pengarang lagu campur sari yang bertemakan patah hati, maka dari itu didi mendapatkan julukan sebagai The God Father of Broken Heart. Cidro merupakan single terbaru yang dia tulis. Keberadaan didi sebagai subjek yang memiliki kecemasan yang dipicu oleh rasa kehilangan. "cidro" dalam bahasa indonesia merupakan cidera atau luka. Luka yang dimaksud dapat diasosiasikan dari luka subjek akan rasa kehilangan.

Kompleks Oedipus, manusia harus menempuh tiga fase yang berhubungan dengan tiga ranah (register) atau tatanan (order) psikisnya, yaitu: fase pra-oedipal pada tatanan Real (the Real), fase cermin pada tatanan Imajiner (the Imaginary), dan fase odipal pada tatanan Simbolik (the Simbolic). Aku merupakan manifestasi dari subjek. Dan (-mu) merupakan objek yang berasal dari kata kamu. Subjek terdapat pada bait ke dua dan ke tiga. Subjek pertama terlihat pada kata (nasib + ku) yang menjadi kata kerja kepemilikan

10 Faruk, Metode Penulisan Sastra: Sebuah Perjalanan Awal (Yogyakarta: Pustaka Pelajar, 2012), h. 196. 
dan diartikan sebagai nasib-nya subjek. Kemudian subjek terlihat jelas pada bait ke empat "aku". Aku subjek diartikan sebagai aku yang memanifestasikan subjek DK.

DK mendapatkan julukan sebagai the god father of Broken Heart karena dari beberapa lirik lagunya menceritakan tentang patah hati. DK mengatakan dalam sebuah konsernya di solo bahwa dia menuliskan lagu-lagunya berdasarkan inspirasi dari perasaan kehilangan. Subjek "aku" mengidealkan kehadiran objek "kamu" atau (-mu dalam bentuk kepemilikan).

Sebuah subjek aku terbentuk karena terdapat objek kamu. Di mana objek ini merupakan bagian dari pembentuk identitas “aku”. Subjek aku akan memiliki keterpenuhan jikan objek kamu dapat melengkapi kebutuhankebutuhan dari aku. Seperti di jelaskan oleh Lacan, seorang bayi dapat membentuk subjek jika terdapat orang tua (Ayah dan ibu). Keberadaan subjek menjadi tidak stabil ketika anak terpisah dari ibu di mana dijelaskan oleh Lacan bahwa ibu dipersepsikan sebagai bagian diri anak, dan kemunculan Ayah sebagai pengacau yang lain bahwa si anak tidak lagi mnejadi bagian dari ibu.

Subjek dengan menggunakan (S) dengan Subjek dengan menggunakan(s) dan juga terdapat subejrk (S') hal ini keterhubungan antara tripel odipal yang dijelaskan oleh Freud yang mana ketiganya merupakan hubungan antara Ayah-Ibu dan Anak, akan tetapi oleh Lacan diidealkan sebagai subjek yang simbolik. Dalam lirik lagu tersebut terdapat $\mathrm{S}$ besar sebagai penanda "aku lirik" dan "aku pengarang". sedangkan s (kecil) merupakan subjek yang kehadirannya menjadi subjek yang dihasrati oleh S/S'.

Bahasa menjadi hadir ketika subjek menyadari kekosongan, dan bahasa sendiri merupakan akibat dari kekosongan. Momen kekosongan itu merupakan momen ketidak hadiran ibu yang dirasakan anak. Alam bawah sadar mengidealkan kehadiran ibu dengan bahasa. hal ini bahasa bekerja untuk mengisi kekosongan dan sekaligus menjadi akibat dari kekosongan tersebut. subjek Aku membuat bahasa melalui metonimi sebagai "signifier" di mana Aku liris diartikan sebagai kekurangan anak akan kehadiran subjek yang dihasratinya tersebut.

Faruk mengatakan bahwa bahasa merupakan sebuah tatanan kultural yang menanamkan subjektivitas bagi manusia, membuat manusia menemukan identitas atau dirinya. Namun, apa yang dilakukan bahasa pada subjek itu bersifat mendua: di satu pihak memberikan rasa subjektivitas, di lain pihak menjauhkan sang subjek dari diri asalinya. Bahasa, dengan demikian, justru memperkuat rasa kurang dan rasa kehilangan di atas. ${ }^{11}$ keterpisahan subjek dengan dirinya yang dimaksud merupakan diri subjek dengan ego-nya. Subjek "aku" mendapatkan keterpenuhan dari (s) kecil. Keterpenuhan tersebut memecah Subjek menjadi $S$ dan (S'), hal inilah yang mencoba dijelaskan oleh Lacan.

Hasrat subjek adalah subjek (kamu) yang disiratkan bahwa (s) memberikan perasaan bahagia dan juga rasa sakit ketika subjek tidak lagi merepetisi perasaan bahagia tersebut. pada bait pertama $\mathrm{S}$ menjelaska bahwa (s) tidak

11 Faruk, Sastra Sebagai Produk dan Produksi Kebudayaan sebuah De-konstruksi (Yogyakarta: Yasayo, 2012), h. 196.

el Bidayah: Journal of Islamic Elementary Education Volume 1, Nomor 2, September 2019 
resiprokal terkait kebahagiaan yang disiratkan dalam "kebak jeroning dada". Dalam artian Aku liris tidak mendapatkan kebahagiaan yang sama dari (s) subjek kecil yang dihasrati.

Keterpisahan Subjek ini mengakibatkan momen kekosongan, momen kekosongan di mana subjek dengan yang dihasratinya tidak menemukan titik temu kemudian memunculkan bahasa sebagai sebuah akibat dari kekosongan tersebut. bahasa di sini adalah deretan dari lirik lagu DK yang bisa diberikan judul "Cidro" yang berarti luka. DK sebagai subjek ingin mendeskripsikan bagaimana luka subjek atau DK yang menginternalisasi subjek yang memiliki luka.

"Cidro" merupakan sebuah kaibat dan sekaligus mengisi kekosongan. Selanjutnya subjek menjelaskan lebih jauh lagi yang menjadi penyebab dari luka tersebut. plot dari lagu tersebut pertama dalah terdapat subjek aku dengan (s) kamu, kemudian subjek mengidealkan tentang hubungan antar subjek yang saling mengisi namun subjek (s) tidak memberikan keterpeenuhan tersebut sehingga mengakibatkan luka darisubjek $\mathrm{S}$, dan menjadikan S' menggantikan peran subjek yang kecewa terhadap (s) melalui bahasa.

Whereas metonymy emphasizes the incessant sliding of signifiers and the delaying of a fixed signified, metaphor is the structure that allows the emergence of signification. The Lacanian formulation of the metaphorizing process runs as follows ' $\mathrm{f}(\bullet £) \mathrm{S}^{\wedge} \mathrm{S}(+) \mathrm{s}$ ', "indiquant que c'est dans la substitution du signifiant au signifiant que se produit un effet de signification."' Originally, the signifier $\mathrm{S}$ is a latent signifier with respect to $\mathrm{S}^{\prime}$. Si s one of the innumerable signifiers $S^{\prime}$ refers to or is connected with. Indeed, every signifier has a whole set of other signifiers attached to itself vertically (on the paradigmatic axis).

Metonimi di dalam lirik ini menunda penanda, di mana dalam Bacher dijelaskan bahwa sifat dari metonimi ini mempersekutukan sekaligus memisahkan. Terdapat penanda "cidro" (luka) yang berhubungan dengan penanda "cinta". Keduanya merupakan penanda yang saing berhubungan. Dalam metonimi ini diidentifikasi bahwa kedua penanda tersebut merupakan bagian dari hasrat subjek. Misalkan, dalam perasaan cinta terdapat kesenangan yang juga masuk dalam cinta itu sendiri, namun juga terdapat luka yang disebutkan subjek sebagai "cidro".

Pada rantai bahasa metonimi tidak berhenti pada dua penanda saja. hal ini dijelaskan oleh Lacanian bahwasanya rantai penanda tidak akan pernah berhenti, dan akan terjadi pengulangan. Misalkan saja terdapat subjek (aku-kamu-cidrocinta-aku- (mengulang)). Tujuan dari metonimi ini adalah mengidentifikasi penanda dan hasrat subjek. Hasrat subjek yang dikatakan oleh Lacanian merupakan ketaksadaran, dan melalui ketaksadaranlah hasrat subjek terbentuk.

Misalkan saja dalam kisah cinta yang lain antara laila dan qais dalam cerita Laila Majnun. Qais mengatakan bahwa laila dan dirinya telah menjatu, aku adalah laila, dan qais adalah laila, aku berada dalam diri laila. Inilah yang terjadi pada subjek Aku dan (-mu) di mana subjek tersebut tak teridentifikasi dalam sebuah subjek yang memiliki nama. Akan tetapi ketika terwujud dalam sebuah bahsa (menjadi sebuah penanda), wujud subjek 
lain selain aku muncul dalam bentuk hasrat aku, yakni cinta dan cidro.

Secara metafora bahasa pada perspektif Lacanian, makna tidak tertutup sehingga makna tidak akan pernah puas dengan satu. Misal dicontohkan sebuah bunga mawar dapat dikaitkan dengan makna romantis dan tanda cinta, akan tetapi makna tida berhenti dari dua hal itu, makna juga dapat berarti lain seperti berduka, ataupun kematian. Dari ke empat makna tersebut tidak bisa berhenti.

Pada tataran metaforis ini, cidro bisa diartikan sebagai sebuah fase patah hati terhadap sebuah hubungan antara sepasang kekasih, ataupun bisa diartikan sebagai subjek yang merasakan kecemasa akibat keterasingan dan berusaha membahasakan keterasingannya dengan metafor-metafor layaknya hubungan antar kekasih, akan tetapi hal ini hanya seputar diri dan ego, antara kesadaran dan ketaksadaran.

Dalam tataran metaforis ini sebenarnya makna bisa menghubungkan teks lirikal dengan teks yang ada di luar lirikal, di mana teks tersebut juga menjelaskan bagaimana hasrat subjek ini. memang benar jika dalam postrukturalisme di mana aliran ini merupakan aliran yang diimani oeh Lacan, di mana pengarang tidak mati. DK tentuntya hadir sebagai subjek pun juga sebagai alter subjek dari ribuan subjek yang ada di dunia nyata.

\section{Kesimpulan}

Postrukturalisme mengidealkan sebuah subjek yang bebas, di mana sebuah bahasa tidak terhubung dengan satu makna saja. tidak ada kebenaran tunggal dalam postrukturalisme. Sehingga pada penganut postruk seperti derida mengatakan bahwa sejarah tidak memiliki titik akhir. Dalam konsep dekonstruksinya bahwa setiap penanda tidak memiliki akhir dalam penandaannya, yang ada hanyalah jejak.

Dalam tulisan ini hanya ingin menunjukan bagaimana konstruksi bahasa Lacan yang ingin menggantikan konsep bahasa Saussure di mana antara petanda dan penadan bersifat kesepakatan dan arbitrase. Di sini lacan tidak memberikan patokan tentang penanda, bahkan keberadaan subjek psikoanalisa dihidupkan oleh Lacan untuk mengidentifiksi hasrat (psikoanalisa) melalui bahasa. otonomi subjek ini berpengaruh terhadap terjadinya hasrat yang berbentuk metafora dan metonimi.

\section{Daftar Pustaka}

Bracher, Mark, dan Jaques Lacan. Diskursus dan Perubahan Sosial: Pengantar Kitik-Budaya Psikoanalisi. Diterjemahkan oleh Gunawan Admiranto. Yogyakarta: Jala Sutra, 2009.

Faruk. Metode Penulisan Sastra: Sebuah Perjalanan Awal. Yogyakarta: Pustaka Pelajar, 2012.

—. Sastra Sebagai Produk dan

Produksi Kebudayaan sebuah Dekonstruksi. Yogyakarta: Yasayo, 2012.

Hartono, Agustinus. Skizoanalisi Deleuze Guattari: Sebuah Pengantar Genealogi Hasrat. Yogyakarta: Jala Sutra, 2007.

Hiasa, Fina. "Kerinduan Pada yang Real Dalam Novel Akar Karya Dee." Jurnal POETIKA 4, no. 2 (30 Desember 2016): 66.

https://doi.org/10.22146/poetika.15650.

Hill, Philip. Lacan Untuk Pemula. Yogyakarta: Kanisius, 2002. 
Lacan, Jacque, dan S. Tomaselli. The Ego

in Freud's Theory and in the Technique of Psycoanalysis. London: W.W. Norton \& Company, 1988.

Lacan, Jacques. Ecrits: A Selection.

Terjemahan Alan Sheridan. London:

Tavistock, 1977.

Sarup, Madan. Panduan Pengantar Untuk

Mehami Postrukturalisme dan

Postmodernisme. Diterjemahkan oleh

Medhy AgintaHidayat. Yogyakarta: Jala

Sutra, 2011. 